\title{
Identifying Value Creation Strategies in the Brand Communities of Sport Clubs Based on the Use of Social Media
}

\author{
${ }^{1}$ Tahereh Seifi Salmi ${ }^{*},{ }^{1}$ Noshin Benar, ${ }^{2}$ Habib Honari \\ ${ }^{1}$ Department of Sport Management, Faculty of Sport Sciences, University of Guilan, Guilan, Iran. \\ ${ }^{2}$ Department of Sport Management, Faculty of Sport Sciences, Allameh Tabataba'i University, Tehran, Iran.
}

Submitted 10 December 2018; Accepted in final form 07 January 2019.

\begin{abstract}
Background. The consumer of a brand is able to influence brands through the use of social media, and this implies why the active relationship between consumers, brand and brand owners is important In the field of sports, fans as club customers also have the ability to influence the brand, including creating value. Therefore, investigating value creation strategies in brand communities based on the use of social media by the clubs' fans is a tangible necessity. Objectives. The current study is conducted to identify the value creation strategies in members of the brand community of fans in social media. Methods. The research has a qualitative design. At the initial stage, using library studies, important value creation factors were extracted and categorized into four categories related to branding, product, interaction and networking. In the second stage, a qualitative tool was used for coding and interpreting. The research process included the conduction of a semi-structured interview with 15 academic and executive experts of sports marketing and social media. Results. The findings of this study showed that four factors related to the value creation strategy including branding, effectiveness, networking and dynamization were identified regarding the value creation done by fans of professional clubs in social media. Conclusion. The overall conclusion obtained by the experts' point of view in terms of value creation done by fans in social media is that it is necessary to focus on these four areas professionally.
\end{abstract}

KEY WORDS: Value Creation Strategy, Branding, Effectiveness, Networking and Dynamization, Football.

\section{INTRODUCTION}

Sport is a great and growing industry. Especially, football is one of the great phenomena in terms of attractiveness for people of any age, gender and nationality (2). We can benefit from the presence of fans, clubs and sports organizations in the social media as a participatory platform (3). Social media has changed the ways in which the fans communicate with the team, the athlete and the clubs, many of the fans are active in the social media, and this activity plays an important role in their lives (4). Due to the popularity of social media, clubs spend a lot of time and resources on attracting the most active fans in social media (5). The concept of the brand community and social media reaches to each other at one point, which is society or community. Brand communities are in principle places (physical or virtual) in which people admire a particular brand and individuals in these communities and they provide a suitable environment for social activities through admiring the brand (6).

Brand communities form a social organization that reflects the brand's special position in

*. Corresponding Author:

Tahereh Seifi Salmi, PhD

Department of Sport Management, Faculty of Sport Sciences, University of Guilan, Khalij-e-Fars Highway, Guilan, Iran.

E-mail: t.seifi1989@yahoo.com 
everyday life of fans and more communication channels between the brand and the fans (7). Consumers of community can be considered as the unlimited source of loyalty for the brand; they act as brand advertisers; they are completely loyal and are less likely to replace their choice with another brand; members of the brand community of a sport club provides important feedbacks on the brand of the sport club; the emotional bond between the brand and members of the community makes members of the community more interested in sharing the brand's success. In this way, loyalty to the brand of the sport club will lead to the brand's expansion. The brand love influences a variety of aspects related to the behavior of the customers of a sports club. Customers' loyalty is one of these behavioral aspects (8). The existence of a brand community plays an important role in creating specific values. Brands are intrinsically a social entity that has been shaped and changed in communities, they show brand position on the everyday lives of members of the brand community as well, and they state a manner in which the brand relates members of brand community to the brand and to other members (6).

The research conducted in the field of sport has defined social media as a media with new technology for facilitating interaction and collaboration, which provided the opportunity for the development and sharing of generated content among organizations (such as teams, clubs, fans, government and non-governmental organizations, and media groups) and individuals (such as athletes, fans, journalists). Smith et al. (2000) have considered brand fans as committed customers with strong emotional bonds with brand and to have a high degree of participation in the purchase or offering the brand to other customers (9). As a result, brand owners and custodians identify the dimensions that have a great effect on creating competitive advantage by recognizing and expanding the values of members of the brand community and can focus on these elements in marketing strategies and allocate more resources to it.

Different studies carried out inside and outside the Iran have studied the brand community and fans. Among the previous researches, Han et al. (2018) have investigated the necessity of developing brand communities in Chinese companies (10). Katz, Ward, and Heere (2018) in a research using two network theories and team identification, have presented a behavioral model for sports fans to participate in international ice hockey games. The results of the research showed that in order to obtain complete understanding of fans' behavior, psychological and structural factors related to the behavior should be taken into account (11). Keshtidar et al. (2018) in their research on fans of professional football leagues have concluded that investing in the brand credibility of professional clubs would strengthen brand identity among fans (12). Rayat, Rayat, and Rayat (2017) in a study titled Development of Brand Community in the New Iranian Sports Teams, have stated that the engagement of the fans for several years, the creation of historical moments, the championship results achieved by the teams, and the establishment of common rituals between the team and fans are excellent examples regarding the brand communities (13). Habibi, Laroche, and Richard (2016) have investigated the effect of three variables including social responsibility, common awareness, customs and traditions as social media-based brand community variables (7). Saeednia, Ghahremani, and IranNejad Parisie (2016) in their research have used four variables namely communication among members, value creation strategies, and loyalty and trust to investigate the effect of social media-based brand community (6). Yoshida et al. (2014) have found that the emotional bond of fans of a community is the only predicting factor for the continuous presence of fans in the brand community (14). McCarthy et al. (2014) in their research also have studied on the interaction and relation between members of the brand community with each other and brand, and ultimately, they focused on the loyalty to report on the state of supporting communities (3). While, Laroche, Habibi, and Richard (2013) has adopted the component of the common identity to explain the variable of the brand community (15). In a broad analysis, Shell et al. (2009) have introduced four effective strategies that can be used by customers to manage brand communities: 1) Social networking; 2) Interaction with the community; 3) Effect management; 4) The use of the brand (16). Auty (2002) in his study introduced fans' brand communities as an ideal forum for empowering fans with the most effect and least cost to mobilize group support of fans (17). 
In brief, today club managers are looking for ways constantly to identify and take advantage of new opportunities in order to respond to hidden demands and future demands (18). It is necessary for marketers to use this phenomenon as an opportunity, because they can communicate with members of the community easily and focusing on the concept of value and value creation can help to clubs as economic firms in order to adopt the appropriate strategies for competition and survival in a new competitive environment. Strategy in sport management is always used as executive strategies for implementing a program. Considering the importance of the position of fans in sport as well as the significant effect of cultural, social, political and economic factors of each region on the development of applied strategies, the necessity for reviewing the value-creation strategies in the fans' community of professional Iranian football clubs is well visible. This is while the technology is upgrading the communications between individuals rapidly, and the fans' community is not detached from this issue. But due to the lack of research in the field of valuecreation strategies by fans of professional Iranian football clubs based on the use of the social media, the researcher chose a qualitative kind of research. Therefore, this research seeks to identify the appropriate strategies for managing brand's fan communities in the social media.

\section{MATERIALS AND METHODS}

Methodology. The present research is conducted to identify the value-creation strategies in the brand communities of sports clubs based on the use of social media using a qualitative method.

Participants. 15 experts, including professors and physical education specialists, sports marketing, social media and sports sociologists, were selected through a targeted and snowball sampling method to conduct a semi-structured interview. The sample size in the qualitative section was determined based on the theoretical saturation.
Tool. The research tool is a semi-structured interview that has been developed using the theoretical frameworks (theories, models, and scientific frameworks). In this research, the definition of brand community proposed by Habibi and Laroch (2013) and the definition of common value creation strategies proposed by Shal et al (2009) have been used $(15,16)$.

Data Analysis. In this research, the qualitative analysis of the theme has been used. In this analysis, the findings are carried out in 6 steps. The first step is to become familiar with the data, which is investigated carefully through frequent readout of data searching for the common meanings in all the interviews. The second step is the creation of initial codes from data. In the third step, the codes obtained will be categorized into themes with specific concepts. In the fourth stage, the themes are reviewed to prevent repetition and overlap. In the fifth step, naming is done using the concept and content of each theme and the qualitative report is presented at the final stage. In this research, after thorough investigation of the results obtained by 15 interviews, first 180 codes were identified manually. In the following, the codes were interpreted and categorized into similar concepts. Common concepts were categorized into 16 codes during frequent readout. After a thorough review of these 16 codes, they were categorized into 4 themes (effectiveness strategy, branding strategy, dynamization strategy, and networking strategy). In order to ensure the validity and reliability of the data collected by the qualitative method which is called scientific accuracy and stability, the method of checking by the interviewees was used.

\section{RESULTS}

The demographic characteristics of the research samples showed that the highest percentage of interviewees was related to academic professors of sport management with $53 \%$ of the total interviewees (Table 1).

Table 1. Interviewees' information

\begin{tabular}{c|c|c}
\hline Position of interviewed people & Frequency & Percentage \\
\hline Academic professors of sport management & 8 & $53 \%$ \\
Marketing professors & 4 & $26 \%$ \\
Expert of media & 3 & $20 \%$ \\
\hline Total & 15 & $100 \%$ \\
\hline
\end{tabular}


The first category was networking strategy related to the fans in social media that after frequent readout of output data obtained from interviews was encoded in 4 codes, as follows in Table 2.

Table 2. Networking strategy and codes

\begin{tabular}{ll}
\hline Strategy & \multicolumn{1}{c}{ Code } \\
\hline $\begin{array}{l}\text { 1. Regular communication of club managers with fans in social media } \\
\text { 2. Assisting in the quantitative and qualitative development and promotion of the } \\
\text { strategy }\end{array}$ & $\begin{array}{l}\text { 3. Developing a particular behavior for fans as a symbol of the club's fans } \\
\text { 4. Providing special occasions for the fans by the club and sending a message to them }\end{array}$
\end{tabular}

The second category included strategies for the effectiveness of fans in social media. These strategies have been extracted based on the club's products including competitions and club products. The following table information is also provided in 4 codes after frequent readout of the interviews (Table 3).

Table 3. Effectiveness strategy and codes

\begin{tabular}{ll}
\hline Strategy & \multicolumn{1}{c}{ Code } \\
\hline 1. Moving towards creating interest among fans \\
2. Presenting products and championship results by the club \\
3. Gaining support from fans of the club products \\
4. Making fun goods for fans
\end{tabular}

The third category included dynamization strategies related to fans in social media. These strategies were presented in 4 codes with the aim of more dynamization in interactions with fans in the club (Table 4).

Table 4. Dynamization strategy and codes

\begin{tabular}{ll}
\hline Strategy & \multicolumn{1}{c}{ Code } \\
\hline $\begin{array}{l}\text { 1. Understanding the needs of fans and making sense regarding the } \\
\text { importance of fans for the club } \\
\text { strategy }\end{array}$ & 2. Encouraging the active participation of fans in the social media \\
3. Considering feedback of fans in social media \\
4. Sharing information transparently and quickly with fans
\end{tabular}


The fourth category consisted of brand strategies related to fans in the social media. These strategies target the performance of fans towards the brand, and after frequent readout the interviews were presented in four codes (Table 5).

Table 5. Branding strategy and codes

\begin{tabular}{|c|c|}
\hline Strategy & Code \\
\hline \multirow{4}{*}{ Branding strategy } & 1. Developing activities related to club brand in social media (increasing the channel). \\
\hline & 2. Increasing the quality and up-to-date images of the club's brand in social media \\
\hline & 3. Conducting matches between fans in social media on various occasions \\
\hline & 4. Encouraging fans to promote club brand in social media \\
\hline
\end{tabular}

\section{DISCUSSION}

The participation of fans in creating value for the club is a significant topic in sports marketing approaches and methods (12). Accordingly, it is necessary for managers of professional football clubs to identify and use different strategies to develop communication with their fans (1). Today, the new technology has paved the way for managers to a great deal by providing a new generation of social media and provided a good context for this goal. In the present research, the effectiveness strategy relied on the product and focused on creating a good feeling regarding the brand among fans of the brand community of professional football clubs about the club and its products. These activities include advertisement, promotion and confirmation by customers who recommend the brand, share good news about brand, and discuss about branding for encouraging others (6). The results of the research with respect to this strategy include moving toward creating interest among fans, delivering products with good results, gaining support from fans, and presenting entertaining products to fans. As it can be seen, from the experts' point of view, these four strategies can be effective in creating a good sense among fans of the brand. As a result, satisfied fans promote their satisfaction in the social media, which will have an effect on the value creation of the club brand. Networking strategy is introduced through collection of communication patterns between two or more members of a group that are together with centrality of their own commonalities (16). These relationships are formed with the goal of information exchange and problem solving and have a relative durability. Therefore, it is not out of the mind that creating communication networks between fans is welcomed; this is while today's technology is at the service of human beings, in order to make the communication to be available to members of the communities as quickly and efficiently as possible (5). The results of this section include four general strategies such as establishing regular relationships between club fans and authorities, helping to promote relations of fans in social media, offering specific behaviors for fans who can introduce himself as the fan of the team on social media (Including wearing club products, choosing a club brand as a profile image and such behaviors), and eventually holding special occasions with the presence of fans will induce this valuable sense and will help them to enjoy the engagement created. The creation of fan networks will enhance the quality of interactions and will keep the fans for the club as an important asset.

The dynamization strategy is formed by a group of time -related activities with the aim of creating an active interest and participation of fans in the brand community (7). The results of the research showed that four strategies including understanding the needs of fans and creating a sense of being important as fans for the club, encouraging active participation of fans in the social media, considering the feedback from fans in the social media and the sharing information transparently and quickly with fans are effective in order to create and enhance interactions between brand and fans. In fact, the definition and 
implementation of mechanisms for the proper communication of the fans of club could be a good prospect for the active and effective participation of fans in value creation for the brand of clubs.

In this research, branding strategy means to develop a brand created by fans in social media for value creation (13). The results of the research include four strategies including the development of activities related to the club brand in social media (increasing the channel), increasing the quality and up-to-date images of the club brand in social media (up-to-date images of players, coach, team outcomes ), holding matches between fans in social media on various occasions (in order to induce the belief of being important as fans for the club) and encouraging fans to publish and promote the brand in the social media in this regard.

\section{CONCLUSION}

The research approach is to create value by fans for the club based on the use of social media environment, the research results are presented in four areas including club products, branding, networking and the dynamization of communication between the fans. The results indicate that from the view of experts regarding the value creation by fans in social media, it is necessary to work on these four domains professionally and apply the strategies to club brand in order to develop it as an asset and capital. The present research is conducted qualitatively and due to the use of experts point of view, important dimensions may be ignored; therefore, it is suggested that the research to be conducted quantitatively and also on the fans. Besides, Future researchers can use these strategies as a mediating factor for promotion and growth of brand-based behaviors, such as loyalty and brand confidence among fans.

\section{APPLICABLE REMARKS}

- Branding strategy has been wellproven to increase brand value as an asset, so it is suggested to hold competitions and programs for brandcentric fans to promote this asset.

- Effectiveness strategy is based on the products of the club, it is suggested that the club managers to focus on the products of the club and how to present the products to these strategies.

- Networking strategy is a way to promote relationships of fans; the presence of fans around the club brand in social media should be organized. It is suggested that the managers to be active further in the development of communicative channels in this area and increase the interactions in order to use existing capacities appropriately.

- Dynamization strategy is also a good way to improve the quality of interactions in social media and move towards raising the brand value of the club. Encouraging fans to reflect their opinions and maintain their interaction with the club is a good mechanism for value creation by fans.

\section{REFERENCES}

1. Tajvidi M, Richard M-O, Wang Y, Hajli N. Brand co-creation through social commerce information sharing: The role of social media. Journal of Business Research. 2018;In Press(In Press):In Press. [DOI:10.1016/j.jbusres.2018.06.008]

2. Adamson G, Jones W, Tapp A. From CRM to FRM: Applying CRM in the football industry. Journal of Database Marketing \& Customer Strategy Management. 2006;13(2):156-72. [DOI:10.1057/palgrave.dbm.3240292]

3. McCarthy J, Rowley J, Jane Ashworth C, Pioch E. Managing brand presence through social media: the case of UK football clubs. Internet Research. 2014;24(2):181-204. [DOI:10.1108/IntR-08-2012-0154]

4. Popp B, Woratschek H. Introducing branded communities in sport for building strong brand relations in social media. Sport Management Review. 2016;19(2):183-97. [DOI:10.1016/j.smr.2015.06.001]

5. Filo K, Lock D, Karg A. Sport and social media research: a rewiew. Sport Management Review. 2015;18(2):16681. [DOI:10.1016/j.smr.2014.11.001]

6. Saeednia H, Ghahremani A, Iran Nejad Parisie M. The Outcomes of Social Media Based Brand Communities' Impact on Brand Trust and Brand Loyalty. Brand Management. 2016;3(2):65-88. 
7. Habibi MR, Laroche M, Richard M-O. Testing an extended model of consumer behavior in the context of social media-based brand communities. Computers in Human Behavior. 2016;62:292-302. [DOI:10.1016/i.chb.2016.03.079]

8. Alavai SM, Najafi Siahroodi M. Brand loyalty role between Brand love and Brand advocacy (A case study: Malavan Anzali sport brand). Applied Research of Sport Management. 2014;3(9):23-36 [Article in Farsi].

9. Smith DR, Padilla WJ, Vier D, Nemat-Nasser SC, Schultz S. Composite medium with simultaneously negative permeability and permittivity. Physical review letters. 2000;84(18):4184. [DOI:10.1103/PhysRevLett.84.4184] [PMID]

10. Han M, Wu J, Wang Y, Hong M. A Model and Empirical Study on the User's Continuance Intention in Online China Brand Communities Based on Customer-Perceived Benefits. Journal of Open Innovation: Technology, Market, and Complexity. 2018;4(4):1-20. [DOI:10.3390/joitmc4040046]

11. Katz M, Ward RM, Heere B. Explaining attendance through the brand community triad: Integrating network theory and team identification. Sport Management Review. 2018;21(2):176-88. [DOI:10.1016/i.smr.2017.06.004]

12. Keshtidar M, Shajie K, Ebrahimian Besharat M, Yousefi M. Structural Model of the Role of Brand Trust on Brand Identity through the Mediating Role of Brand Love among Fans of Futsal Premier League Clubs in Iran. Annals of Applied Sport Science. 2018;6(1):65-74. [DOI:10.29252/aassjournal.6.1.65]

13. Rayat A, Rayat M, Rayat L. Development of Brand Community in Iranian New Sport Teams. Annals of Applied Sport Science. 2017;5(1):105-15. [DOI:10.18869/acadpub.aassjournal.5.1.105]

14. Yoshida M, Gordon B, Nakazawa M, Biscaia R. Conceptualization and measurement of fan engagement: Empirical evidence from a professional sport context. Journal of Sport Management. 2014;28(4):399-417. [DOI:10.1123/jsm.2013-0199]

15. Laroche M, Habibi MR, Richard M-O. To be or not to be in social media: How brand loyalty is affected by social media? International Journal of Information Management. 2013;33(1):76-82. [DOI:10.1016/j.ijinfomgt.2012.07.003]

16. Schau HJ, Mu-iz Jr AM, Arnould EJ. How brand community practices create value. Journal of marketing. 2009;73(5):30-51. [DOI:10.1509/jmkg.73.5.30]

17. Auty C, editor Football fan power and the Internet: net gains? Aslib Proceedings; 2002: MCB UP Ltd.

18. Afkar A, Tojari F, Zarei A. Testing the Structural Model of Purchase Intention of Sport Consumers based on Value-Attitude-Behavior Hierarchy. New Trends in Sport Management. 2018;6(20):39-50. 